\title{
PEMBERDAYAAN KETERAMPILAN RETORIKA DAKWAH SANTRI PONDOK PESANTREN MIFTAHUL ULUM PANDEAN WONOREJO BANYUPUTIH SITUBONDO
}

\author{
Nur Ainiyah \\ Universitas Ibrahimy Situbondo, Indonesia \\ nura_ifan@yahoo.com
}

\begin{abstract}
This assistance is aimed to train students in improving speaking skills in order to make easy in conveying messages and ideas to others. It is Located in Miftahul Ulum Islamic Boarding School. It has two research problems, they are, (1) How is the speaking skill empowerment through discourse techniques to the students in building public speaking communication? (2) How are the obstacles faced by students in Miftahul Ulum Islamic Boarding School?. The assistant explores interview data and documentation data by the data analysis technique. The results show that (1) The activities of muhadharah discourse training in Miftahul Ulum Islamic Boarding School is carried out once a week on Saturday evening. (2) With great motivation, the students will carry out activities with focus on the objectives of the learning process. (3) Muhadharah is carried out by all caretakers and all students in Miftahul Ulum Islamic Boarding School.
\end{abstract}

Keyword: Pidato, Khitobah, Muhadharah dan Komunikasi

\section{Pendahuluan}

Kehidupan manusia tidak bisa dipisahkan dari bahasa. Karena bahasa merupakan alat komunikasi yang digunakan oleh masyarakat ${ }^{1}$.

${ }^{1}$ Kurniasari, Anna Nurlaila, Sarikata Bahasa dan Sastra Indonesia Super komplet, (Yogyakarta: CV. Solusi Distribusi, 2014), 2. 
Alat komunikasi tersebut berupa lambang bunyi serta suara. Suara tersebut dihasilkan oleh alat ucap manusia. Bagaimanapun wujudnya, setiap masyarakat pastilah memiliki bahasa sebagai alat komunikasi. Sebagaimana yang sudah kita ketahui, bahwa komunikasi adalah suatu proses penyampaian informasi (pesan, ide, gagasan) dari pihak pemberi kepada pihak penerima ${ }^{2}$. Seseorang yang memiliki keterampilan berbicara mudah dalam menyampaikan pesan, ide, dan gagasan kepada orang lain, keberhasilan menggunakan pesan, ide, dan gagasan itu dapat diterima oleh orang yang mendengarkan atau yang diajak bicara. Sebaliknya seseorang yang tidak memiliki keterampilan berbicara akan mengalami kesulitan dalam menyampaikan ide gagasannya kepada orang lain.

Di era globalisasi saat ini kemampuan untuk berbicara sangat dibutuhkan baik berbicara dalam konteks resmi maupun tidak resmi, karena seseorang mampu menyampaikan apa yang dikehendakinya melalui bicara. Kemampuan seseorang untuk berbicara biasanya tidak sama tergantung bagaimana orang tersebut mampu berfikir secara kritis dalam menghasilkan kata-kata sehingga masih banyak orang yang sulit untuk berbicara di depan umum dalam menyampaikan sesuatu. Namun, banyak orang yang menganggap hal tersebut tidak penting.

2 Adha, Kholifatul, Panduan Mudah Public Speaking, (Yogyakarta: PT Buku Kita, 2014), 6. 
Padahal sangat penting untuk menguasai bahasa agar dapat menyampaikan pesan, ide, dan gagasan kepada orang lain. Memang tidak mudah untuk mahir berbicara di depan umum tanpa adanya pengalaman dan wawasan yang luas. Untuk itu perlu adanya dorongan motivasi agar lebih berani untuk tampil berbicara didepan umum, sebagaimana ayat berikut:

"Dan hendaklah ada di antara kamu segolongan umat yang menyeru kepada kebajikan, menyuruh kepada yang ma'ruf dan mencegah dari yang menkar, merekalah orang-orang yang beruntung" (Q.S. Ali Imran:104).

Pondok pesantren merupakan lembaga pendidikan yang pertama mengembangkan lingkungan hidup dalam arti kata pengembangan sumber daya manusia dari segi mentalnya ${ }^{3}$. Di dalam pondok pesantren terdapat santri yang sedang mempelajari ilmu agama. Aktifitas santri dilakukan setiap hari sejak pagi hingga malam hari. Santri selalu ditekankan supaya dapat mendalami ilmu agama Islam agar dapat mendakwahkan ajaran-ajaran agama Islam, baik untuk dirinya sendiri maupun untuk orang lain atau kepada seluruh umat Islam secara umum.

Demikian pula di Pondok Pesantren Miftahul Ulum, yang mana

${ }^{3}$ Ghazali, Bahri, Pesantren Berwawasan Lingkungan, (Jakarta: CV. Prasasti, 2001), 20. 
mewajibkan seluruh santri untuk dapat mengikuti segala bidang pendidikan serta pengajaran baik itu kegiatan kurikuler maupun ekstrakurikuler. Para santri juga diharuskan agar dapat berdakwah dengan metode yang baik. Untuk mencapai tujuan itu pondok pesantren modern Miftahul Ulum menerapkan kegiatan muhadharah. Kegiatan muhadharah di Pondok Pesantren Miftahul Ulum adalah termasuk dalam kegiatan ekstrakurikuler.

Sedangkan kegiatan kurikuler formalnya mencakup aktivitas yang ada di sekolah, dan kurikuler pesantrennya antara lain pengkajian kitab-kitab klasik/ kuning seperti Nahwu Sorof, Fiqih, Aqidah/ Tauhid, Hadits dan lain-lain. Adapun kegiatan ekstrakulikuler meliputi muhadharah, muhadatsah, pembacaan Berzanzi, dan membaca Al-Qur'an. Muhadharah adalah metode berdakwah, guna melatih santri dalam berdakwah, sehingga para santri tidak merasa canggung apabila santri tersebut akan berdakwah kepada masyarakat. Di dalam kegiatan tersebut seluruh santri diwajibkan untuk selalu mengikuti kegiatan muhadharah setiap seminggu sekali dengan bimbingan para Ustad/Uztadzah dan segenap pengurus.

Pada dasarnya muhadharah merupakan langkah awal sebagai salah satu upaya dalam menyiapkan kader da'i yang membentuk santri dari yang belum berani berpidato, kurang mampu menjadi bisa maupun bahkan menjadi lebih baik dalam menyampaikan isi ceramahnya 
kepada santri lainnya. Permasalahan yang hendak diselesaikan dalam pengabdian ini meliputi: 1) Bagaimana pemahaman dan pelaksanaan Muhadharah santri pondok pesantren miftahul ulum? Dan 2) Apa saja yang menjadi kendala pelaksanaan muhadharah bagi santri pondok pesantren miftahul ulum?

Tujuan pengabdian yang dilakukan, pertama, mengetahui sejauh mana pemahaman santri terhadap muhadharah di lingkungan pondok pesantren miftahul ulum dan kedua, untuk mengurai kendala yang dihadapi santri terkait penerapan konsep konsep muhadharah di lingkungan pondok pesantren miftahul ulum

\section{Metode dan Teknik Dampingan}

Strategi yang digunakan dalam pemberdayaan masyarakat ini adalah dengan menggunakan pendekatan pengabdian masyarakat berbasis Participatory Rural Appraisal'. Strategi ini diharapkan data problematika masyarakat yang dijelaskan di atas (latar belakang) dapat ditelaah kembali, didalami bersama-sama untuk kemudian direncanakan alternatif problem solvingnya bersama masyarakat. Sehingga dapat menumbuhkan kesadaran bersama karena mereka

4 Sukardi, Metodelogi Penelitian Pendidikan, Kompetensi dan Prakteknya. (Jakarta: Bumi Aksara, 2005), 241-247. 
terlibat di dalamnya, dan tim berperan hanya sebagai fasilitator.

Adapun dalam implementasinya, program ini akan dilakukan melalui beberapa cara atau metode-metode sebagai berikut:

Pertama, memberikan pemahaman terhadap santri tentang apa itu organisasi dan keorganisasian secara konseptual dan teknis.

Kedua, penguatan pemahaman penting berorganisasi untuk melatih kemandirian santri sehingga santri siap menjadi agen perubahan dalam masyarakat.

Ketiga, menyusun laporan kegiatan, yaitu mendeskripsikan aktivitas program ini dalam bentuk narasi secara tertulis.

\section{Laporan Dampingan dan Temuan}

\section{Gambaran Umum Lokasi Pendampingan}

Pondok pesantren Miftahul Ulum berlokasi di dusun Pandean desa Wonorejo kecamatan Banyuputih kabupaten Situbondo. Yakni sebuah wilayah administratif yang berbatasan dengan wilayah kabupaten Banyuwangi. Sebagai pondok pesantren yang tinggal di wilayah perbatasan dengan jarak yang cukup jauh dari kota kabupaten dan kecamatan karena melewati hutan atau alas sejauh $25 \mathrm{KM}$, menjadikan pesantren mengantungkan fasilitas layanan publiknya pada kabupaten banyuwangi terutama pelayanan kesehatan, telepon, pasar dan listrik Banyuwangi.

Pondok pesantren ini dibawah pimpinan kepengasuhan 
KH.Zainullah Johar dan Nyai Hj. Rosyidah Mufidah. Pondok pesantren miftahul ulum memiliki beberapa lembaga pendidikan diantaranya: 1) SMK Miftahul Ulum; 2) MTS Miftahul Ulum; 3) MI Miftahul Ulum; 4) RA Miftahul Ulum; 5) PAUD Miftahul Ulum; 6) TPQ Miftahul Ulum; 7) Diniyah Ula Miftahul Ulum; 8) Diniyah wustho Miftahul Ulum; 9) BMK Miftahul Ulum. Dan ada beberapa kegiatan lain seperti mengkaji kitab kuning, kegiatan berorganisasi dan pelatihan khitobah.

Santri merupakan calon pemimpin bagi masyrakat minimal bagi dirinya sendiri. Melalui dunia ornagisasi sesungguhnya para santri dapat memetik pelajaran mengenai kepemimpinan, menagerial, kedisiplinan, kemandirian dan kemasyarakatan dll. Betapa dunia keroganisasian sangat berperan vital dalam membentuk karakter santri. Dalam kehidupan bersama di pesantren maupun masyarakat luas nanti tidak akanterlepas dari organisasi.

Dunia pesantren sendiri dihuni oleh santri dari berbagai kultur dan kelas akan tetapi dengan satu aturan yang sama yang diterapkan oleh pesantren mereka tinggal bersama dengan perlakuan sama. Peraturan yang ada tidak kemudian menjadi sebuah solusi atas masalah yang dihadapi santri secara berkelompok sehingga penting bagi santri untuk belajar dan menerapkan konsep konsep keorganisasian. Maka dari itu pendamping dalam hal ini secara kontinyu melakukan pendampingan secara teoritis dan praktis terhadap kegiatan kegiatan 
santri baik yang sudah terprogram maupun yang aksidental.

\section{Kondisi Saat ini Masyaakat Santri Dampingan}

Jumlah dari keseluruhan santri pondok pesantren miftahul ulum mencapai kurang lebih 500 orang akan tetapi yang merupakan santri mukim hanya sekitar 150 orang yang terdiri dari santri putra dan putri. Adapun usia santri mukim berkisar 12 tahun sampai 21 tahun terdiri dari siswa mts, smk dan mahasiswa. Usia 12-21 tahun merupakan ketegori usia remaja dimana pola pikirnya seperti remaja lainnya yang tidak tinggal di pondok pesantren sehingga beberapa pelanggaran kecil yang dilakukan santri seperti memiliki handphone, keluar tanpa izin, bolos sekolah dan pelanggaran kecil lainnya. Sesekali terjadi perselisihan dan pertengkaran kecil diantara mereka. Kondisi ini menyebabkan mereka belajar atas peristiwa-peristiwa yang mereka alami sehingga menjadi dewasa dan berperilaku sopan.

Ada beberapa kegiatan santri saat ini diantaranya:

Tabel 1

Kegiatan Harian Santri Pondok Pesantren Miftahul ulum

\begin{tabular}{|c|c|l|}
\hline No & Waktu & \multicolumn{1}{|c|}{ Kegiatan } \\
\hline 1 & $04.00-05.00$ & $\begin{array}{l}\text { Bangun tidur, Qiyamul Lail Subuh } \\
\text { berjamaah }\end{array}$ \\
\hline 2 & $05.00-05.40$ & $\begin{array}{l}\text { Kegiatan mengaji dan pembelajaran di } \\
\text { kelas } \\
\text { dengan kajian kitab kuning, bahasa, }\end{array}$ \\
\hline
\end{tabular}




\begin{tabular}{|c|l|l|} 
& & $\begin{array}{l}\text { penguatan bidang Tahfidzul Qur'an dan } \\
\text { ilmu } \\
\text { Eksak }\end{array}$ \\
\hline 3 & $05.00-07.00$ & MCK dan sarapan pagi \\
\hline 4 & $07.00-12.45$ & $\begin{array}{l}\text { Kegiatan Belajar Mengajar di kelas } \\
\text { Formal } \\
\text { dan Diniyah }\end{array}$ \\
\hline 5 & $12.30-13.30$ & Sholat Dzuhur dan Makan Siang \\
\hline 6 & $13.30-15.30$ & Kegiatan Belajar Mengajar di kelas \\
& & $\begin{array}{l}\text { Formal } \\
\text { dan Diniyah }\end{array}$ \\
\hline 7 & $15.30-16.00$ & Sholat Ashar berjamaah \\
\hline 8 & $16.00-17.00$ & Ekstrakulikuler, musyawarah Al-Qur'an \\
\hline 9 & $17.00-17.30$ & MCK, persiapan masuk masjid \\
\hline 10 & $17.30-18.00$ & $\begin{array}{l}\text { Baca Al-Qur'an, kitab, serta sholat } \\
\text { maghrib } \\
\text { Berjamaah }\end{array}$ \\
\hline 11 & $18.00-19.30$ & Mengaji Al-Qur'an dengan musyawir \\
\hline 12 & $19.30-20.30$ & Sholat Isya' berjamaah, makan malah \\
\hline 13 & $20.30-21.45$ & Mengaji, belajar mandiri \\
\hline 14 & $21.45-22.00$ & $\begin{array}{l}\text { Pemberian Mufrodat/ kosakata bahasa } \\
\text { Arab } \\
\text { dan Inggris }\end{array}$ \\
\hline 15 & $22.00-22.30$ & Kegiatan Mujahadah \\
\hline & & \\
\hline
\end{tabular}


Tabel 2

Kegiatan Mingguan Santri Pondok Pesantren Miftahul ulum

\begin{tabular}{|c|l|l|}
\hline No & \multicolumn{1}{|c|}{ Jam } & \multicolumn{1}{|c|}{ Jenis Kegiatan } \\
\hline 1 & Malam Rabu & Seni Baca Al-Qur'an \\
\hline 2 & Malam Jumat & Tahlilah, sholawat berjanji, Ad Dhiba' \\
\hline 3 & Malam Ahad & Khithabah \\
\hline 4 & Senin Sore & Qiro'atul Qur'an \\
\hline 5 & Kamis Sore & $\begin{array}{l}\text { Tahlilan/Ziyarah kubur (Putra). } \\
\text { Sholawatan (Putri) }\end{array}$ \\
\hline 6 & Jumat Sore & $\begin{array}{l}\text { Tahlilan/Ziarah kubur (Putri) } \\
\text { Sholawatan (Putra) }\end{array}$ \\
\hline 7 & Sabtu Sore & PRAMUKA \\
\hline 8 & Ahad Pagi & Kegiatan Bahasa dan Olah Raga \\
\hline
\end{tabular}

\section{Kondisi Yang Diharapkan}

Melalui kegiatan pembinaan santri ini diharapkan memberi manfaat kepada para santri mampu dan dapat mengembangkan materi yang telah disajikan baik pada diri sendiri maupun pada orang lain dengan penuh rasa tanggung jawab, jujur, dan terbuka. Melalui kegiatan ini diharapkan para santri akan menjadi kader-kader baru secara berkesinambungan dan berkelanjutan sehingga materi yang diterima dapat dirasakan pula manfaatnya oleh pihak lain (masyarakat).

\section{Strategi Pelaksanaan}

1. Kegiatan ini pertama menyajikan materi khitobah secara umum. 
2. Simulasi khitobah dalam bentuk bahasa yang mudah dipahami dan bisa dipraktekkan.

\section{Kajian Teori}

\section{Konsep Santri}

Istilah santri terdapat di pesantren sebagai pengejawantahan adanya peserta didik yang haus akan ilmu pengetahuan yang dimiliki oleh seorang kyai yang memimpin sebuah pesantren ${ }^{5}$. Santri pada dasarnya berkaitan erat dengan keberadaan kyai dan pesantren.. Oleh karena itu santri merupakan elemen penting dalam suatu lembaga pesantren. Mengenai macam-macam santri sebagai berikut. Zamakh Stari Dhofier mengatakan bahwa di dalam proses belajar mengajar ada dua tipologi santri yang belajar di pesantren, antara lain'6:

Pertama, Santri Mukim. Santri Mukim yaitu santri yang menetap, tinggal bersama kyai dan secara aktif menuntut ilmu dari seorang kyai. Dapat juga secara langsung sebagai pengurus pesantren yang ikut bertanggung jawab atas keberadaan santri lain. Setiap santri yang mukim telah lama menetap dalam pesantren secara tidak langsung bertindak sebagai wakil kyai. Ada dua motif seorang santri menetap sebagai santri mukim: a) Motif menurut ilmu artinya santri itu datang 2001), 22.

${ }^{5}$ Ghazali, Bahri, Pesantren Berwawasan Lingkungan, (Jakarta: CV. Prasasti,

${ }^{6}$ Ghazali, Bahri, Pesantren, 23. 
dengan maksud menuntut ilmu dari kyainya; dan b) Motif menjunjung tinggi akhlak, artinya seorang santri belajar secara tidak langsung agar santri tersebut setelah di pesantren akan memiliki akhlak yang terpuji sesuai dengan akhlak kyainya.

Kedua, Santri Kalong. Santri kalong pada dasarnya adalah seorang murid yang berasal dari desa sekitar pondok pesantren yang pola belajarnya tidak dengan jalan menetap di dalam pondok pesantren, melainkan semata-mata belajar dan secara langsung pulang ke rumah setelah belajar di pesantren. Jadi, sebuah pesantren yang besar didukung oleh semakin banyaknya santri yang mukim dalam pesantren di samping terdapat pula santri kalong yang tidak banyak jumlahnya. Seorang santri pergi dan menetap di suatu pesantren karena berbagai alasan: 1) Ingin mempelajari kitab-kitab lain yang membahas Islam secara lebih mendalam di bawah bimbingan kyai yang memimpin pesantren tersebut, 2) Ia ingin memperoleh pengalaman kehidupan pesantren, baik dalam bidang pengajaran, keorganisasian maupun hubungan dengan pesantren-pesantren yang terkenal, dan 3) Ia ingin memusatkan studinya di pesantren tanpa disibukkan oleh kewajiban sehari-hari di rumah keluarganya ${ }^{7}$.

Oleh kerena itu seorang santri yang menetap dan pergi ke sebuah

7 Dhofier, Zamakhsyari, Tradisi Pesantren: Studi Tentang Pandangan Hidup Kyai., (Jakarta: LP3ES, 1985), 52. 
pesantren yang jauh dan masyhur merupakan suatu keistimewaan bagi seorang santri yang penuh cita-cita. Ia harus memiliki keberanian yang cukup penuh ambisi, dapat menekan sebuah rindu kepada keluarganya, maupun teman-teman sekampungnya, sebab setelah selesai pelajarannya di pesantren ia diharapkan menjadi serang alim yang dapat mengajar kitab-kitab dan memimpin masyarakat dalam kegiatan keagamaan.

Jadi, dalam pembahasan di atas dapat disimpulkan bahwa motivasi santri adalah dorongan yang ada pada santri dan yang hanya dapat dilihat pada aktivitas fisiknya yang mengarah pada tujuan tertentu yang ingin dicapai, hanya dengan motivasi yang kuat, santri tersebut akan lebih menunjukkan minatnya, aktivitasnya, dan partisipasinya dalam mengikuti kegiatan belajar yang ada di dalam pesantren tersebut.

\section{Konsep Dasar Muhadharah}

Muhadharah berasal dari kata - yang berarti hadir, sebagai mashdar mim menjadi yang artinya ceramah atau pidato. Pidato bisa disamakan dengan Retorika (Yunani) atau Public Speaking (Inggris). Pidato mempunyai arti "suatu seni penyampaian berita secara lisan yang isinya bisa berbagai macam". Pidato adalah tehnik pemakaian kata-kata atau bahasa secara efektif yang berarti ketrampilan atau 
kemahiran dalam memilih kata yang dapat mempengaruhi komunikasi sesuai dengan kondisi dan kondisi komunikasi tersebut.

Dalam berpidato ada tiga unsur yang amat penting, yaitu komunikator, pesan, dan komunikan ${ }^{8}$.

Komunikator adalah pembicara, pesan adalah masalah yang dibicarakan, dan komunikan adalah pendengar yang menerima pesan. Dengan demikian dapat dikatakan bahwa berpidato itu perbuatan menyampaikan pesan oleh pembicara kepada pendengar. Sedangkan dalam bahasa jawa disebut sesorah atau pidato yang artinya berbicara, mengungkapkan gagasan di depan orang banyak secara lisan dengan teknik tertentu. Pidato dikatakan berhasil jika mampu mempengaruhi, membujuk, atau mengubah suasana hati orang yang mendengarkannya. Dengan demikian, pidato menjadi sarana yang sangat penting untuk mencapai berbagai tujuan, terutama dalam hidup bermasyarakat.

Orang yang berpidato selalu berhubungan dengan orang banyak, seseorang berbicara secara langsung di atas podium atau mimbar dan isi pembicaranya diarahkan pada orang banyak, baik hanya sekedar informasi, pesan ataupun sesuatu untuk dilaksanakan oleh orang-orang yang mendengarkan pesan atau informasi tersebut ${ }^{9}$. Dari

${ }^{8}$ Wiyanto. 2004. Terampil Menulis Paragraf. Grasindo. Jakarta. 43.

${ }_{9}$ Hakim, L Membangun Web Berbasis PHP Dengan Framework CodeIgniter, (Yogyakarta: Lokomedia, 2010), 201. 
dulu sampai sekarang, pidato atau public speaking masih menjadi salah satu bagian kebudayaan umat manusia yang cukup dominan dalam menyampaikan informasi, mengabarkan sebuah pesan, menjelaskan ideide, menyebarluaskan ilmu pengetahuan atau menjelaskan penemuanpenemuan mereka kepada orang lain untuk diikuti dan sebagainya.

Pidato adalah suatu ucapan dengan susunan yang untuk disampaikan kepada orang banyak. Pidato yang baik memberikan kesan positif bagi orang-orang yang mendengar pidato tersebut. Kemampuan berpidato atau berbicara yang baik di depan publik juga dapat membantu untuk mencapai jenjang karir yang baik. Pidato merupakan penyampaian gagasan, pikiran, atau informasi kepada orang lain secara lisan dengan metode-metode tertentu. Ada juga berpidato merupakan seni percakapan atau seni berkata-kata yang didukung dengan wawasan keilmuan yang luas dan dapat dipertanggungjawabkan.

Berpidato dalam dunia pesantren sering disebut dengan khithabah dan orangnya disebut khatib (Hakim, 2010: 8). Kita dapat melihat orang yang memiliki kecakapan dan memiliki kepandaian dalam berpidato dalam forum-forum kenegaraan, penajian, ceramah, diskusi, debat, seminar, kampanye, partai politik, pelatihan-pelatihan, dan lain sebagainya.

Jadi, yang dimaksud dengan muhadharah adalah salah satu cara untuk menyampaikan informasi, menyebarkan sebuah pesan, 
menjelaskan ide-ide kepada orang lain, tetapi disini diberi batasan, sekelompok orang yang berkumpul, umpamanya 15 orang atau lebih. Adapun yang dimaksud tujuan tertentu ialah dalam menemukan sesuatu hal, soal, masalah dan sebagainya. Jadi, jika hanya tanpa tujuan atau pokok persoalan, maka bukanlah dinamakan pidato.

\section{Fungsi dan Tujuan Muhadharah}

Fungsi pidato sangat banyak dan beragam, yang kesemuanya akan merujuk pada tujuan yang hendak dicapai dengan adanya pidato tersebut, dapat disebutkan, fungsi-fungsi pidato tersebut diantaranya adalah: memberikan informasi, menyampaikan pesan, mendidik, Menghibur, Membujuk, Menarik perhatian, Memperingatkan dan Membentuk kesan.

Dengan banyaknya fungsi-fungsi pidato di atas maka fungsi yang sering digunakan adalah memberikan informasi, yang bertuajuan untuk menyampaikan informasi atau keterangan kepada pendengar, agar diharapkan untuk mengetahui, mengerti, dan menerima informasi yang disampaikan.

Selaim yang perlu diperhatikan dalam Muhadharah adalah Etika dalam Muhadharah Etika di atas podium hampir sama dengan gerakan di atas podium, perilaku pembicara semenjak dari mulai maju sudah menjadi perhatian, sampai selesai menyelesaikan pidatonya. Ketika 
berpidato harus mencakup beberapa hal antara lain: a) Gerak-gerik Tubuh, b) Pentingnya Aksi Tubuh, c) Menjelaskan makna, d) Mencapai tekanan, e) Ekspresi wajah, f) Postur tubuh dan g) Gerakan.

\section{Pelaksanaan Pemberdayaan}

\section{Profil kegiatan}

Pondok pesantren Miftahul Ulum merupakan lembaga pendidikan yang memiliki konsentrasi seperti pondok pesantren umumnya yang ada di Jawa Timur. Dengan visi dan misi untuk mencetak Santri secara keilmuan dan mandiri. Berbagai pengetahuan umum dan agama diberikan pada santri termasuk pengetahuan dan keilmuan yang sifatnya praktis. System sorogan yang masih dilakukan di yakini akan memberi pengetahuan yang barokah. Sedangkan pengetahuan yang sifatnya membangun skill diberikan pada santri untuk mengasah kemampuan santri sehingga ketika sudah lulus siap berinteraksi danbersaing dalam lingkungan sosialnya.

Materi teknik pidato diberikan untuk mengasah keterampilan dan bakat santri yang memiliki kecenderungan dalam melakukan ceramah. Hal ini meskipun tidak sampai pada mencetak penceramah professional, keahlian ini akan membantu santri dalam membangun mental, spiritual, kemandirian dan kepercayaan diri ketika menghadapi 
situasi dan tantangan dalam masyarakat.

Kegiatan yang dilaksanakan oleh pengabdi ini merupakan salah satu bentuk dari kegiatan yang telah direncanakan dan diprogramkan dalam rangka pemberdayaan santri pondok pesantren miftahul ulum wonorejo situbondo yang dilaksanakan oleh kepala bidang pendidikan diharapkan menjadi santri yang handal "beramal-ilmiah berilmu amaliah".

\section{Implementasi Kegiatan Muhadharah Bagi Santri}

Kegiatan muhadharah di Pondok Pesantren Miftahul Ulum telah dicetuskan sejak awal tahun 1992 dimana mewajibkan seluruh santri untuk mengikuti kegiatan muhadharah. Seperti diketahui, bahwa pesantren ini dikenal dengan bahasa asing bahasa Arab dan bahasa Inggris. Jadi, kegiatan muhadharah di pesantren ini menggunakan 4 bahasa yaitu bahasa Arab, bahsa Inggris, bahasa Indonesia, dan bahasa Jawa. Dengan adanya dukungan pengasuh, ustadz, pengurus, santri mampu mengikuti dan melaksanakan kegiatan ekstrakulikuler muhadharah yang ada di pesantren sesuai dengan kegiatan yang sudah dilaksanakan dari awal.

Di Pondok Pesantren Miftahul Ulum kegiatan muhadharah terpandang dengan bahasa asing. seperti hasil wawancara penulis kepada beberapa nara sumber, eluruh santri harus mampu menguasai kosa kata yang diberikan oleh pengurus untuk memudahkan menyusun teks pidato dengan bahasa yang baik. Setiap pembagian tugas pidato 
berbeda-beda, yang membedakan kelas 7,8, dan 10 untuk teks pidato bahasa asing hanya membuat pembukaan dan penutupan saja. Namun, untuk kelas atas pembuatan teks pidato bahasa asing sudah mencakup pembukaan, isi pidato dan penutup. Sedangkan untuk bahasa lain seperti bahasa Indonesia dan bahasa Jawa seluruh santri sama dalam membuat teks pidato dari pembukaan, isi, dan penutup. Alasan berbeda dengan yang lain tujuannya kelas yang awal (yang baru) fokus untuk menghafalkan dan memahami pembukaan dan penutupan teks pidato bahasa asing.

Sebelum maju pembimbing memberikan pengarahan kepada anak-anak bahwasannya, sebelum berpidato santri harus mengumpulkan teks pidato dan intisari terlebih dahulu untuk dikoreksi oleh pembimbing. Setelah itu setoran agar tau kesalahan santri sebelum maju ke panggung untuk berpidato sehingga pidatonya bisa berjalan dengan lancar. Dari penjelasan pelaksanaan kegiatan muhadharah penulis menyimpulkan bahwa implementasi kegiatan muhadharah adalah suatu penerapan yang diberikan kepada santri untuk memudahkan bagaimana cara melaksanakan kegiatan muhadahrah sesuai dengan peraturan yang sudah dilaksanakan dari awal.

a) Peran Pembimbing Muhadharah kepada Santri

Peran pembimbing sangat penting dalam kegiatan muhadharah tersebut, misalnya mengajak bergegas untuk mengikuti kegiatan 
muhadharah, menilai, dan mengevaluasi kegiatan tersebut setelah selesai mengikuti kegiatan muhadharah.Selaku asatidz juga memberikan dukungan, arahan-arahan dan memantau bagaimana pengurus membimbing santri. Pemibimbing yang berperan aktif adalah pengurus bagian pengajaran.

b) Hambatan Santri

Tidak semua orang memiliki kemahiran dalam berbicara di depan umum. Namun, kemempuan ini dapat dapat dimiliki oleh semua santri melalui proses belajar dan latihan secara berkesinambungan dan sistematis. Setiap kegiatan memiliki kelebihan dan kekurangan. Kelebihan dalam kegiatan tersebut santri dapat berpartisipasi dalam pelaksanaan kegiatan muhadhrah di dalam pesantren, mengikuti perlombaan baik di dalam pesantren maupun di luar pesantren, dan mampu berpidato dengan menggunakan 4 bahasa. Sedangkan kekurangannya biasanya santri sering izin sakit, pulang atau mencari alasan lain supaya tidak mengikuti kegiatan tersebut.

Kegiatan muhadhrah di pesantren lebih efektif santri putri daripada santri santri putra. Kegiatan mahadharah disantri putra kurang maksimal dikarenakan banyak hambatan-hambatan yang dialami oleh masing-masing santri seperti malas untuk membuat teks pidato, lemahnya dalam menguasai kosakata bahasa asing, dan sering kabur di luar pondok. Berbeda dengan kegiatan yang ada disantri putri, 
mereka selalu berperan aktif dalam mengikuti berbagai kegiatan yang ada di dalam pesantren.

c) Hukuman Bagi Santri

Dalam pelaksanaan proses pendidikan tentu tidak terlepas dari ganjaran (penghargaan) dan hukuman baik pada pendidikan umum, dininyah, maupun kegiatan ekstrakulikuler. Umumnya para santri yang menaati peraturan yang ada maka akan mendapatkan hadiah, sedangkan santri yang melanggar maka akan mendapatkan hukuman. Salah satunya dalam kegiatan muhadharah ada peraturan untuk memberikan hukuman kepada santri jika tidak bisa menghafalkan pidato. Hukumannya jika tidak hafal satu kali, maka hukumannya berdiri diruangan sendiri. Hukuman yang kedua apabila tidak hafal maka santri berdiri diruang yang lain. Tidak halal ketiga santri diberdirikan dilapangan. Tidak hafal keempat santri terpaksa diberdirikan diruang putra, begitu sebaliknya jika putra berulang-ulang tidak hafal maka dikirimkan keruang santri putri.

Selain itu setiap ruang masing-masing berunding untuk memberikan hadiah bagi santri yang pidatonya terbaik. Dengan memberikan hadiah seperti itu memberikan semangat dalam mengikuti kegiatan muhadharah tersebut.

Adanya santri diberi hukuman justru mendidik santri agar lebih disiplin. Bukan hanya disiplin waktu tetapi juga disiplin menaati 
peraturan kegiatan yang sudah dijalankan selama ini.

d) Peran Santri dalam Kegiatan Muhadharah

Peran santri selalu aktif dalam mengikuti kegiatan-kegiatan yang ada di pesantren, baik dalam pendidikan formal, pendidikan non formal dan kegiatan ekstrakulikuler. Dalam kegiatan muhadharah tidak hanya berlajar berpidato di depan orang banyak saja, dalam kegiatan tersebut dibagi menjadi 4 kelompok antara lain:

1) Kelompok A: bagian dekorasi dan intisari

Sebelum kegiatan dimulai tugas kelompok A mendekorasi ruangan deindah mungkin, dari merias panggung, menata meja dan kusri dan merias papan tulis. Santri lain bertugas untuk meyampaikan intisari dari pidato yang sudah disampaikan di depan panggung.

2) Kelompok B: tugas MC

3) Ketika kegiatan dilaksanakan yang bertugas menjadi protocol (MC) sembuka acara yang akan dilaksanakan pada malam hari ini. Selain yang bertugas MC kelompok B juga bertugas untuk membaca sholawatan sebelum acara pidato.

4) Kelompok C: tugas pidato

5) Bagi santri yang mendapatkan tugas pidato menyampaikan di depan panggung yang sudah disiapkan oleh petugas dekorasi. Berpidato dengan menggunakan sistem diroling setiap minggunya. Jadi setiap bulannya dari 4 kelompok mendapat tugasnya secara merata. 
6) Kelompok D: hiburan

7) Sebelum acara penutup ada hiburan yang ditampilkan dari kelompok D. Adapun hiburan yang akan ditampilkan di depan bermacam-macam, biasnya dari kelompok tersebut mendiskusikan hiburan apa yang akan ditampilkan sebelum penutup. Biasanya ada yang menampilkan puisi, pantun, stand up comedy dan drama.

\section{Dinamika Keilmuan dalam Realitas Masyarakat Dampingan}

Setiap ilmu memiliki fungsi teoritis dan praktis demikian halnya dengan ilmu komunikasi. Dalam pendampingan santri kali ini dua keilmuan yang saling bersinergi adalah ilmu komunikasi, etika dan teknik pidato. Komunikasi adalah keterampilan yang sangat penting dalam kehidupan manusia, dimana dapat kita lihat komunikasi dapat terjadi pada setiap gerak langkah manusia. Manusia adalah makhluk sosial yang tergantung satu sama lain dan mandiri serta saling terkait dengan orang lain dilingkungannya. Satu-satunya alat untuk dapat berhubungan dengan orang lain dilingkungannya adalah komunikasi baik secara verbal maupun non verbal (bahasa tubuh dan isyarat yang banyak dimengerti oleh suku bangsa).

Beberapa definisi komunikasi adalah: 1) Komunikasi adalah kegiatan pengoperan lambang yang mengandung arti/makna yang perlu dipahami bersama oleh pihak yang terlibat dalam kegiatan komunikasi; 2) Komunikasi adalah kegiatan perilaku atau kegiatan 
penyampaian pesan atau informasi tentang pikiran atau perasaan; 3) Komunikasi adalah sebagai pemindahan informasi dan pengertian dari satu orang ke orang lain; 4) Komunikasi adalah berusaha untuk mengadakan persamaan dengan orang lain.

Komunikasi adalah penyampaian dan memahami pesan dari satu orang kepada orang lain, komunikasi merupakan proses sosial (Modul PRT, Lembaga Administrasi). Etika komunikasi dan teknik pidato Pidato adalah suatu ucapan dengan susunan yang untuk disampaikan kepada orang banyak ${ }^{10}$. Pidato yang baik memberikan kesan positif bagi orang-orang yang mendengar pidato tersebut. Kemampuan berpidato atau berbicara yang baik di depan publik juga dapat membantu untuk mencapai jenjang karir yang baik.

Pidato merupakan penyampaian gagasan, pikiran, atau informasi kepada orang lain secara lisan dengan metode-metode tertentu. Ada juga berpidato merupakan seni percakapan atau seni berkata-kata yangdi dukung dengan wawasan keilmuan yang luas dan dapat dipertanggungjawabkan.

10 Balqis, Khayyirah, Cara Pintar Berbicara Cerdas di Depan Publik, (Yogyakarta: Diva Press, 2013), 41. 


\section{Diskusi Keilmuan}

\section{Profil Pesantren}

\begin{tabular}{|l|l|}
\hline Nama pesantren & Miftahul ulum \\
Alamat & Jl. KHR as'ad syamsul arifin pandean \\
& wonorejo banyuputih situbondo \\
& KH. Ach. Zainullah Johar \\
Pengasuh & 1980 \\
Tahun berdiri & MI, MTS, SMK, PAUD, RA, \\
Lembaga pendidikan & TPQ,MD,MDU \\
\hline
\end{tabular}

\section{Kondisi Pondok Pesantren}

\section{Tabel 2.}

\section{Kondisi Pondok Pesantren Miftahul ulum}

\begin{tabular}{|l|l|l|}
\hline 1 & Kondisi Pondok & \\
\hline a) Jumlah guru/ustadz & $\begin{array}{l}\text { 25orang terdiri dari : ustadz dan } \\
\text { Ustadzah }\end{array}$ \\
\hline b) Jumlah Santri & $\begin{array}{l}502 \text { orang yang terdiri dari : 301Putra } \\
\text { dan 201 putri }\end{array}$ \\
\hline c) Sarana dan Prasarana & $\begin{array}{l}\text { 1 masjid, 22 ruang kelas , 1 lokal } \\
\text { kantor OSBI, 1 lokal ruang ustadz, } \\
\text { lokal kantor Administrasi, 1 lokal } \\
\text { perpustakaan mini, 15 } \\
\text { Kamar tidur, 1 kamar tamu, 1 } \\
\text { gudang, 1 kantin, 8 kamar } \\
\text { mandi/toilet, 1 kamar UKS. 20 unit } \\
\text { computer, dan alat }\end{array}$ \\
\hline d) fasilitas lain-lain & Rebana, Lapangan, Sepak bola, \\
& Sound System \\
\hline
\end{tabular}




\begin{tabular}{|l|l|l|}
\hline 2 & $\begin{array}{l}\text { Kondisi Lingkungan } \\
\text { a) Penerimaan Santri }\end{array}$ & $\begin{array}{l}\text { Menerima santri baru setiap tahun } \\
\text { ajaran baru. }\end{array}$ \\
\hline & $\begin{array}{l}\text { Di Tengah pemukiman penduduk, } \\
\text { samping Masjid Al-Muttaqin, luas } \\
\text { tanah 15.000 M }{ }^{2}\end{array}$ \\
\hline & c) Ekonomi Wali Santri & Rata-rata penghasilan per bulan \\
\hline & $\begin{array}{l}400.000,-800.000,- \\
\text { d) Administrasi Santri }\end{array}$ & $\begin{array}{l}\text { Pembayaran bulana per-anak } \\
\text { Rp.310.000/bln }\end{array}$ \\
\hline
\end{tabular}

\section{Sarana dan Prasarana}

Untuk memperlancar proses belajar mengajar di pesantren dan untuk memudahkan interaksi belajar mengajar serta untuk mencapai tujuan pengajaran yang diharapkan, maka adanya sarana dan prasarana sangatlah penting. Untuk dapat melaksanakan kegiatan belajar mengajar dengan baik, Pondok Pesantren Miftahul Ulum memiliki sarana dan prasarana yang cukup memadai, yaitu asrama, kamar mandi, ruang belajar, tempat bermain, dapur umum dan ruang pertemuan.

\section{Struktur Organisasi}

Pondok Pesantren Miftahul ulum memiliki 2 buah kepengurusan, yaitu kepengurusan putra dan putri. Selain itu ada juga kepengurusan untuk program madrasah. Dalam kepengurusan ini tidak 
semata-mata berdasarkan hasil voting, tetapi juga berdasarkan hasil musyawarah bersama dan disetujui oleh pengasuh.

\section{Follow Up}

Dengan kondisi riel data tersebut, pondok pesatren miftahul ulum masih memiliki kekurangan fasilitas pendidikan dan fasilitas asrama. Adapun tenaga pengajar yang ada semntara masih cukup. Maka sebagai sebuah catatan penting pendamping adalah dengan fasilitas yang terbatas ini maka santri kemudian lebih diarahkan pada sifat kesederhanaan agar tetap bisa belajar meski dengan fasilitas dna prasarana yang terbatas.

\section{Kesimpulan}

1. Kegiatan muhadharah di Pondok Pesantren Miftahul Ulum dilaksanakan setiap seminggu sekali setiap malam minggu. kegiatan muhadharah wajib dilaksanakan baik dari kelas 7, 8, dan 10 . Sedangkan kelas 11 berperan sebagai pengurus. Untuk kelas 7 dan 10 teks pidato bahasa asing hanya pembukaan dan penutupan saja, sedangkan bagi kelas 8 dari pembukaan, isi pidato dan penutupan. Bagi kelas 3 SMP maupun 3 SMA mengikuti kegiatan muhadharah hanya sampai semester satu. Memasuki semester dua kelas 3 SMP maupun 3 SMA sudah dibebaskan tidak mengikuti kegiatan yang ada di pesantren kecuali mengaji. 
2. Pemberdayaan bagi santri dalam melaksanakan kegiatan muhadharah adalah dorongan untuk dapat melakukan publik speaking atau berbicara di depan umum. Motivasi tersebut bersumber dari dua faktor yakni faktor intrinsik seperti kemampuan dalam diri individu untuk melakukan kegiatan di depan umum, dan faktor ekstrinsik yakni kewajiban bagi setiap santri untuk mengikuti kegiatan muhadharah. Selaku pengurus setiap sebelum kegiatan dimulai berplencar untuk mengajak para santri untuk mengikuti kegiatan muhadharah yang sudah diterapkan di dalam pesantren dari awal.

3. Strategi kegiatan muhadharah adalah suatu penerapan yang diberikan kepada santri untuk memudahkan bagaimana cara melaksanakan kegiatan muhadahrah sesuai dengan peraturan yang sudah dilaksanakan dari awal. Sebelum kegiatan muhadharah dilaksanakan segenap pengurus memberitahu kepada seluruh santri untuk mengumpulkan teks pidato dan intisari sebelum maju ke depan. Dengan cara seperti itu mempermudah santri untuk menghafalkan teks pidato dan menyampaikan intisari dari pidato tersebut. Selain itu santri dapat mengikuti kegiatan muhadharah secara efektif. Selain itu untuk mengefektifkan kegiatan muhadharah pengurus menerapkan pola punishment dan reward. Punishment digunakan bagi santri yang tidak hafal untuk menyampaikan pidato, 
sedangkan reward digunakan untuk santri yang aktif dan lebih unggul dalam menyampaikan pidato di depan umum.

\section{Daftar Pustaka}

Adha, Kholifatul. Panduan Mudah Public Speaking. Yogyakarta: PT Buku Kita, 2014.

Arikunto, Suharsimi. Prosedur Penelitian, Suatu Pendekatan Praktek. Jakarta: Rineka Cipta, 1996.

Departemen Agama RI. Al-Qur'an dan Terjemahanya. Jakarta: PT. Syamil Cipta Media, 2005.

Departemen Agama RI. Pembakuan Sarana Pendidikan (Penyelenggaraan Program Wajib Belajar Pendidikan Dasar 9 Tahun pada Pondok Pesantren Salafiyah Tingkat Wustho). Jakarta: Depag, 2005.

Dhofier, Zamakhsyari, Tradisi Pesantren: Studi Tentang Pandangan Hidup Kyai, Jakarta: LP3ES, 1985.

Fanani, Burhan. Buku Pintar Menjadi MC, Pidato, Penyiar Radio \& Televisi. Yogyakarta: Araska, 2013.

Ghazali, Bahri. Pesantren Berwawasan Lingkungan. Jakarta: CV. Prasasti, 2001.

Hakim, Rachman. Kiat Jitu Mahir Pidato. Yogyakarta: Shira Media, 2010. Islamuddin, Haryu. Psikologi Pendidikan. Yogyakarta: Pustaka Pelajar, 2012. 
Jayanti, Reni Dwi. Dahsyatnya Pidato Praktek Public Speaking dan Master of Ceremony (MC) yang Dahsyat. Jakarta: Media Books, 2012.

Khayyirah, Balqis, Cara Pintar Berbicara Cerdas di Depan Publik, Yogyakarta: Diva Press, 2013.

Khayyirah, Balqis. Cara Pintar Berbicara Cerdas di Depan Publik. Jogjakarta: Diva Press, 2013.

Kurniasari, Anna Nurlaila. Sarikata Bahasa dan Sastra Indonesia Super komplet. Yogyakarta: CV. Solusi Distribusi, 2014.

Ma'arif, Zaenal. Komunikasi Etika dan Hubungan Antar Manusia. Semarang: Duta Nusindo. 2007. 